\title{
Retração e Fluência de Concretos de Alta Resistência:
}

\author{
Análise Experimental
}

\author{
Creep And Shrinkage Of High Strength Concretes:
}

An Experimental Analysis

\author{
Gilberto Carbonari ${ }^{1}$; Ravindra Gettu ${ }^{2}$; Antonio Aguado ${ }^{2}$, \\ Berenice M. Toralles Carbonari ${ }^{3}$
}

\begin{abstract}
Resumo
O comportamento de retração e fluência dos concretos de alta resistência é muito diferente dos concretos convencionais. Estes aspectos devem ser adequadamente quantificados para representar as deformações de longa duração do material na analise estrutural e projeto. Este trabalho discute resultados experimentais com o objetivo de determinar as deformações de fluência e retração desde a idade de fabricação, além de comparar os diversos sistemas que podem ser utilizados para medir as deformações. Foram ensaiados no laboratório cinco diferentes concretos sob condições de ambiente controlado, de temperatura e umidade. Os fenômenos que são quantificados podem ser classificados como retração básica e de secagem, e fluência básica e de secagem. Também é apresentada a importância relativa destes mecanismos no concreto de alta resistência.
\end{abstract}

PALAVRAS-CHAVE: Fluência, Retração, Concreto De Alta Resistência, Análise Experimental.

\begin{abstract}
The creep and shrinkage behaviour of high strength silica fume concretes is significantly different from that of conventional concretes. In order to represent the proper time-dependent response of the material in structural analysis and design, these aspects should be adequately quantified. This paper discusses an experimental setup that is able to determine the creep and shrinkage of concrete from the time of placing. It also compares different gages that can be used for measuring the strains. The method is applied to five different concretes in the laboratory under controlled environmental conditions. The phenomena that are quantified can be classified as basic shrinkage, drying shrinkage, basic creep and drying creep. The relative importance of these mechanisms in high strength concrete will also be presented.
\end{abstract}

KEY WORDS: Creep, Shrinkage, High Strength Concrete, Experimental Analysis.

\section{Introduction}

High performance concretes (HPCs) can be defined as a class of concretes that are engineered to exhibit superior properties in order to increase the integrity, safety and service life of structures in a cost-effective manner. These materials not only

\footnotetext{
${ }^{1}$ Universidade Estadual de Londrina, CTU/DE, Cx. Postal 6001, CEP 86051-990, Londrina, PR., Email: carbonar@uel.br.

${ }^{2}$ Universitat Politècnica de Catalunya, Department of Construction Engineering, ETSECCPB, Barcelona, Espanha.

${ }^{3}$ Universidade Estadual de Londrina, CTU/DCCi, Cx. Postal 6001, CEP 86051-990, Londrina, PR., Email: toralles@ uel.br.
} 
possess adequate workability in the fresh state and high strength in the hardened state but can also provide other improved properties such as lower permeability, higher durability and higher stiffness. The most common HPCs are those incorporating silica fume and superplasticizer, and those having low water-cement ratios. They usually have compressive strengths higher than $60 \mathrm{MPa}$. Generally, HPCs are designed to satisfy the critical performance requisites of the structure, including the aspects affecting their production, utilization, maintenance and service behaviour. One important facet of the structural response is the long-term mechanical behaviour, which is governed primarily by the time-dependent mechanisms of concrete, especially those causing creep and shrinkage. Conventionally, such behaviour was considered as a consequence of the material composition and compressive strength, and rarely specified as a performance requisite. However, recent researches have focused on the benefits of using high strength silica fume concretes for long-term structural performance. This has led to the possibility of designing the concrete composition to yield the required time-dependent behaviour. For example, 45

Favre et al. (1992) demonstrated that the longterm deflections of reinforced concrete structures, especially slabs, under service loads can be reduced by up to $50 \%$ with the incorporation of silica fume and the reduction of water content.

The development and the structural utilization of HPCs need the adequate characterization of their time-dependent behaviour. This requires the validation of experimental techniques that can be used to quantify the various mechanisms affecting the creep and shrinkage of HPC. The most important of these mechanisms are basic creep, drying creep, hydration shrinkage and drying shrinkage (ACKER, 1993). From the experimental point of view, basic creep can be defined as the creep that occurs when the surface of the specimen is sealed to prevent moisture transference from and to the environment, drying creep is the one which occurs due to the interaction with the environment, in an unsealed specimen, hydration shrinkage occurs in a sealed specimen or in a surface saturated condition, and drying shrinkage is the one which occurs due to moisture loss in an unsealed specimen. These behavioral aspects are considerably different in HPCs when compared with normal concretes. Due to the low water content and compact microstructure, HPC exhibits lower drying shrinkage and drying creep. The hydration shrinkage, hereafter referred to as endogenous shrinkage, is quite negligible in normal concretes but is significant in HPCs. It can be taken as the combined effect of the chemical or Le Chatalier shrinkage, which occurs due to the volume loss during hydration, the self-dessication shrinkage, which occurs due to the consumption of bonded water for hydration leading to internal drying, and thermal shrinkage due to higher internal temperatures (DE LARRARD; MALIER, 1992; VERNET; CADORET, 1992).

The present work, that is a part of Doctoral Thesis (CARBONARI, 1996), discusses the experimental methodology needed for quantifying the mechanisms leading to creep and shrinkage. Shrinkage was measured on specimens in a fog room at nearly $100 \%$ R.H., and on sealed and unsealed specimens maintained at about 50\% R.H. Creep in the linear range was measured on sealed and unsealed specimens maintained at about $50 \%$ R.H. Additionally, the evolution of the internal temperature of the concrete was also monitored with embedded thermocouple. The ambient temperature was maintained at about $20^{\circ} \mathrm{C}$.

\section{Methodology for experimental characterization}

Creep of concrete is normally determined by measuring the compressive strains of standard specimens at selected age under prescribed environmental conditions, by applying a constant stress of not more than $40 \%$ of the strength (ASTM, 1987). The load is applied in frames that are capable of maintaining the required load in spite of the 
specimen deformation. Drying creep is measured at a temperature of about $20^{\circ} \mathrm{C}$ and a relative humidity of about $50 \%$. Shrinkage is measured similarly but on specimens that are not loaded. In one type of test system, a rigid frame houses the specimen(s) between a spring and a loading plate. An oil jack with a manometer or load cell is normally used to apply the stress. The loading plate is then bolted in place and the deformation of the specimens is compensated by the elongation of the spring. A more sensitive system is the oleopneumatic frame discussed later (Figure 2a).

(a)

(b)
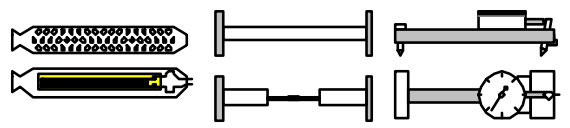

Figure 1. (a) Bonded strain gage, (b) embedded epoxy mold strain gage, (c) embedded extensometers, (d) mechanical extensometer
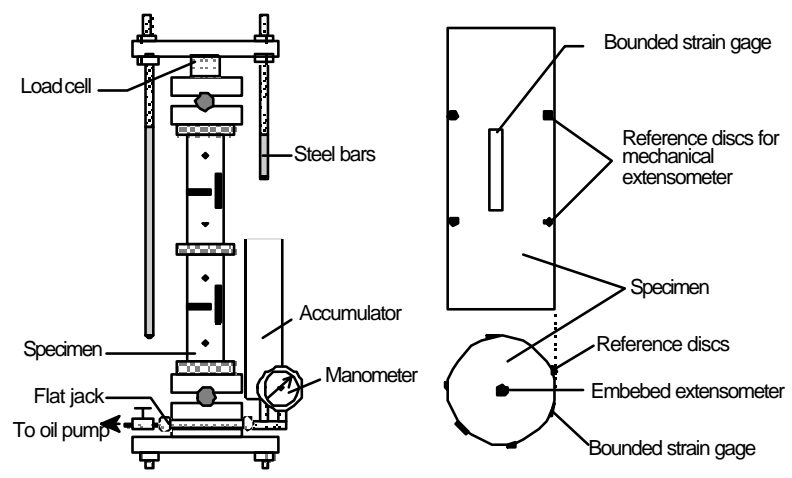

Figure 2. (a) Testing configuration, and (b) Specimen with gage locations

The measurement of the strains requires equipment with a precision of at least 10 microstrains. Such equipment can be embedded in the specimens, attached permanently to their surfaces or portable (ASTM, 1987). Four methods were used in the present study to measure the time-dependent deformations: surface-bonded strain gages, embedded extensometers with strain gages in fullbridge arrangement, embedded epoxy mold strain gages, and a mechanical dial gage based extensometer (Figure 1). The latter was used to manually determine the relative displacements between pairs of steel reference discs glued to the specimen surface. All surface measurements with the strain gages and the mechanical extensometer were made over the center of the specimen, along lines parallel to its longitudinal axis and at $120^{\circ}$ to each other. The embedded gages and extensometers were placed at the center of the specimen, along its axis. The locations of the gages and the reference discs are shown in Figure 2b. The lengths of the strain gages (of Micro-Measurements) were $50 \mathrm{~mm}$ and the gage length for the mechanical extensometer was 150 $\mathrm{mm}$. Embedded extensometers (Tokyo Sokki KM50F and KM-100A) of two lengths, 50 and $100 \mathrm{~mm}$, were used. They measured the relative displacement between two metal discs, one fixed to each end. The embedment strain gage (Micro-Measurements EGP5-120/T) was a $100 \mathrm{~mm}$ long foil gage coated with a polyamide epoxy giving it a prismatic shape (7H19H110 mm). The two broader faces had been molded with indentations to increase the adherence to the concrete. The mechanical DEMEC-type extensometer had a precision of $0.002 \mathrm{~mm}$.

All the surface and embedded strain gages had resistances of 120-ohm and were connected to Wheatstone circuits in quarter-bridge three-wire configuration. A relatively low input of 2 volts was used in order to avoid excessive heating of the strain gages. The output voltage was measured through a multiplexer-based data acquisition system and a digital multimeter with a maximum precision of $6 \frac{1}{2}$ digits (corresponding to $\pm 1 \mathrm{~mm} / \mathrm{m}$ strain). This system was controlled through Hewlett Packard software on a computer with an HP-IB interface board. Both input and output voltages of each Wheatstone bridge were continuously monitored and stored by the computer. The Wheatstone bridge circuits were verified with shunt resistors. The embedded extensometer was agitated with 10 volts and monitored by the same data acquisition system. The temperature of the concrete was measured with embedded thermocouple and a data logger. 
The embedment transducers, embedment strain gages and thermocouple were positioned within the specimen molds before casting, leaving them embedded in the concrete. For the bonded strain gages, the surface of the specimen was prepared by coating it with an epoxy. This coating was cured and polished before the strain gage was glued on with the same epoxy resin. All the electrical devices were connected through shielded cables to avoid desensitization due to interferences.

Two sizes of cylinders were used in the study: $150 \mathrm{H} 450 \mathrm{~mm}$ fabricated in rigid fiber glass molds and 94H282 mm fabricated in rigid PMMA molds. Note that all the specimen dimensions were larger than five times the maximum aggregate size (i.e., 12 $\mathrm{mm}$ ) of the concretes.

The creep tests were performed in oleopneumatic testing machines (Figure 2a) with $25 \mathrm{~T}$ flat jacks. Two specimens were loaded in each steel frame, with steel balls at the top and bottom to compensate for eccentricities and uneven jack deformation. Load was applied by rapidly pressurizing the oil in the jack with a pump. The pressure was monitored with a digital manometer during the loading process and later with a glycerine dial manometer. Additionally, the loads in some tests were monitored with strain gage based load cells. During the first few days of loading, the load losses were compensated by monitoring the oil pressure periodically. A membrane-type nitrogen accumulator was used to stabilize the applied pressure.

\section{Experimental program and results}

Five series of specimens were cast and tested. The compositions of these concretes and their basic properties are given in Table 1 . The specimens were maintained in their molds for at least 24 hours and later in a fog room at about $95 \%$ R.H. and $21^{\circ} \mathrm{C}$ for two days before loading. The specimens of Series 1 and 2 were capped with a sulphur mortar and the specimens of Series 3, 4 and 5 were ground with a diamond disc.
As mentioned earlier, the primary objective of the present investigation was to study the effectiveness of experimental procedures used to quantify the creep and shrinkage mechanisms. The main aspects considered here are discussed in the following sections, along with other results that provide information about the time-dependent behaviour.

Table 1. Compositions (per $\mathrm{m}^{3}$ ) and the basic properties of the concretes used

\begin{tabular}{|c|c|c|c|c|}
\hline Property & Series $1 \quad$ Series 2 & Series 5 & Series 3 & Series 4 \\
\hline Cement type & \multicolumn{2}{|c|}{$\begin{array}{c}\text { Spanish type I-55A } \\
\text { (CEN Class I } 52.5 \mathrm{R}) \\
\mathrm{C}_{3} \mathrm{~S}=45 \%, \mathrm{C}_{2} \mathrm{~S}=23 \%, \\
\mathrm{C}_{3} \mathrm{~A}=10 \%, \mathrm{C}_{4} \mathrm{AF}=9 \% \\
\text { Blaine spec. surf. }=5090 \mathrm{~cm} / \mathrm{g} \\
28 \mathrm{~d} \text { compr. strength }=68.8 \mathrm{MPa}\end{array}$} & \multicolumn{2}{|c|}{$\begin{array}{c}\text { Spanish type I-45A } \\
\text { (CEN Class I 42.5R) } \\
\mathrm{C}_{3} \mathrm{~S}=67 \%, \mathrm{C}_{2} \mathrm{~S}=4 \%, \\
\mathrm{C}_{3} \mathrm{~A}=9.2 \%, \mathrm{C}_{4} \mathrm{AF}=9.6 \% \\
\text { Blaine spec. surf. }=3900 \mathrm{~cm}^{2} / \mathrm{g} \\
28 \mathrm{~d} \text { compr. strength }=62.1 \mathrm{MPa}\end{array}$} \\
\hline Cement content & $550 \mathrm{~kg}$ & $428 \mathrm{~kg}$ & $444 \mathrm{~kg}$ & $462 \mathrm{~kg}$ \\
\hline Sand type & \multicolumn{2}{|c|}{ Siliceous (0- $5 \mathrm{~mm})$} & \multicolumn{2}{|c|}{ River sand ( 0 - $5 \mathrm{~mm})$} \\
\hline Sand content & $690 \mathrm{~kg}$ & $870 \mathrm{~kg}$ & $1020 \mathrm{~kg}$ & $889 \mathrm{~kg}$ \\
\hline Crushed gravel type & \multicolumn{2}{|c|}{ Basalt (5 -12 mm) } & \multicolumn{2}{|c|}{ Limestone (5 $-12 \mathrm{~mm})$} \\
\hline Crushed gravel content & $980 \mathrm{~kg}$ & $870 \mathrm{~kg}$ & $739 \mathrm{~kg}$ & $893 \mathrm{~kg}$ \\
\hline Water content & $190 \mathrm{~kg}$ & $145 \mathrm{~kg}$ & $150 \mathrm{~kg}$ & $153 \mathrm{~kg}$ \\
\hline Superplasticizer type & \multicolumn{4}{|c|}{ Solid napthalene DARACEM 120} \\
\hline Superplasticizer content & $4.18 \mathrm{~kg}^{*}$ & $5.64 \mathrm{~kg}$ & $8.88 \mathrm{~kg}$ & $4.62 \mathrm{~kg}$ \\
\hline Microsilica type & GRACE Force 10000 & Rheobuild & \multicolumn{2}{|c|}{ Elkem (densified powder) } \\
\hline Microsilica content & $110 \mathrm{~kg}$ & $44 \mathrm{~kg}$ & $44 \mathrm{~kg}$ & $46 \mathrm{~kg}$ \\
\hline Slump & $17.5 \mathrm{~cm}$ & $17 \mathrm{~cm}$ & $13 \mathrm{~cm}$ & $20 \mathrm{~cm}$ \\
\hline Compressive strength & $83 \mathrm{MPa}$ & $65 \mathrm{MPa}$ & $75 \mathrm{MPa}$ & $64 \mathrm{MPa}$ \\
\hline
\end{tabular}

* superplasticizer added in two parts

\section{Effect of the method of measurement}

Figure 3 shows measurements made with the embedded strain gage were practically the same as the mean value of the measurements made with the surface-bonded strain gages. The averages of the mechanical extensometer measurements were also the same but the variations were much higher. Moreover, the mechanical extensometer is not recommended at early stages of loading when several frequent measurements have to be made and the deformations are very small. It was observed that the embedded extensometers used in this study exhibited higher initial deformations than the other sensors in the creep tests.

Subsequent examination of the embedded extensometer showed that they undergo buckling during the rapid application of load. No such problems were observed in the shrinkage tests. 


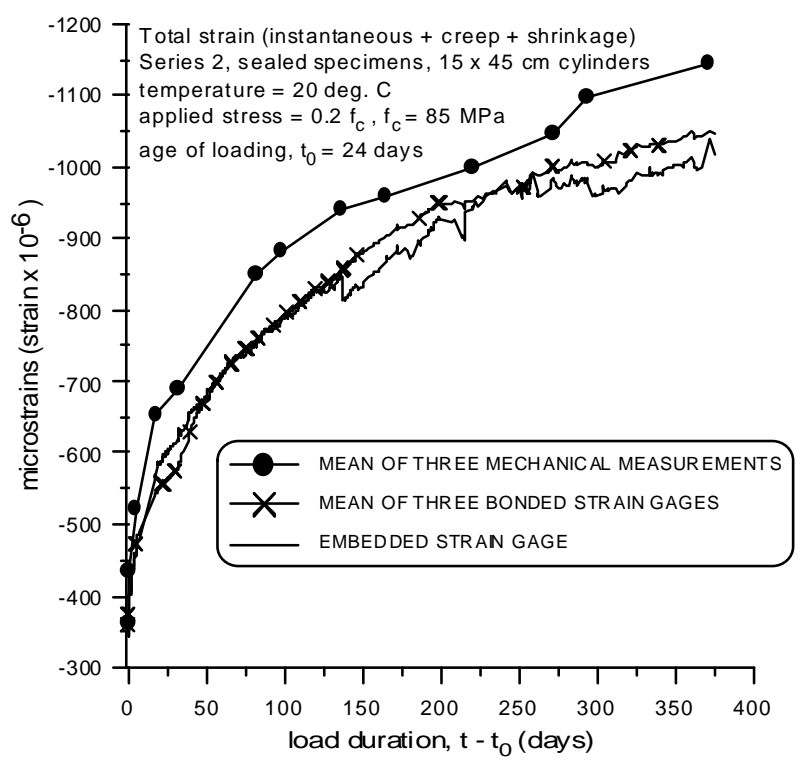

Figure 3. Measurements of deformation made with 3 system.

\section{Effect of variations in humidity}

In order to know the effect of the outside humidity on this concrete, at the end of the 5 differed series tests, the unsealed specimens were submerged in water, instead of being taken to garbage (the ones related to the creep tests as well as to the shrinkage tests) and were tested. The results of this experience are shown in Figure 4, where the creep and shrinkage deformation were considered as a positive signal. The specimens were previously unsealed and therefore, presented a decrease in shrinkage deformation after immersion in water. The fact that the final value of the two specimens are very similar called our attention, as it reflected the fact that the final value is independent of the way and of the fact that the drying shrinkage is a reversible deformation, being only not reversible the corresponding value to the basic shrinkage. In the specimens used in the creep tests, the results of the final deformations after the dip were considered very similar, in line with what was obtained for the shrinkage specimens. This could answer the fact that the drying creep is recoverable while the part not recoverable corresponds to the basic creep. It should be noticed that not all the changes of micro-structure are

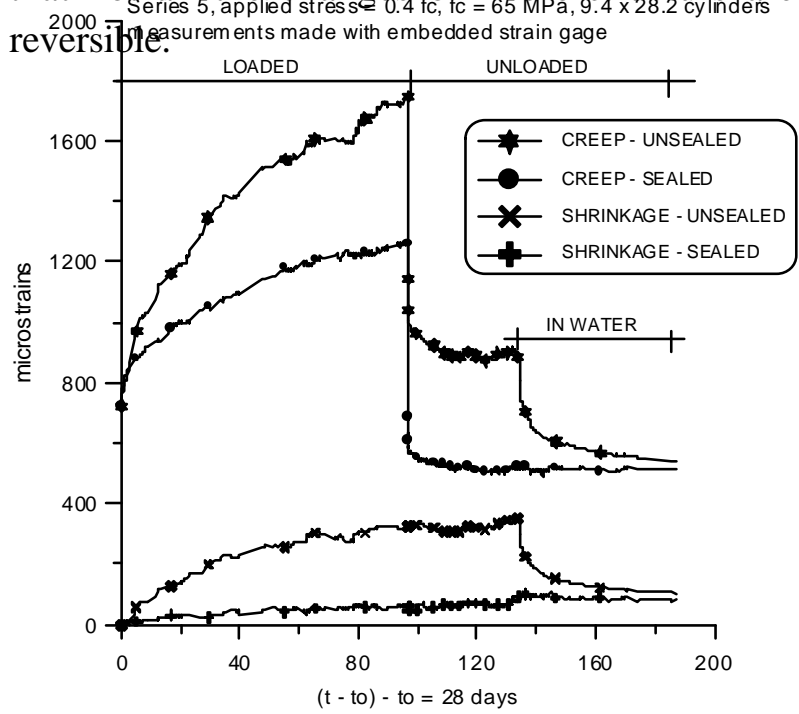

Figure 4. Recovery and unrecoverable deformations

\section{Evolution of temperature and shrinkage during the hardening process}

As noted by several researchers (e.g., LE ROY; DE LARRARD, 1993; TAZAWA; MIYAZAWA, 1993; TAZAWA et al., 1995), silica fume concretes with low water-cement ratios exhibit considerable endogenous shrinkage. This behaviour at very early age is demonstrated in Figure 5. The measurements of shrinkage and specimen temperature were started about 1 hour after casting. The temperature initially decreases to reach a balance with the ambient temperature. This, along with the setting, causes some shrinkage in the period up to 15 hours after casting. The subsequent hydration reactions increase the concrete temperature to about $9^{\circ} \mathrm{C}$ above the ambient temperature. This initially causes expansion, probably due to thermal effects, and later considerable shrinkage (in the order of 200 microstrains). The measurements were made while the specimen was in the mold. 


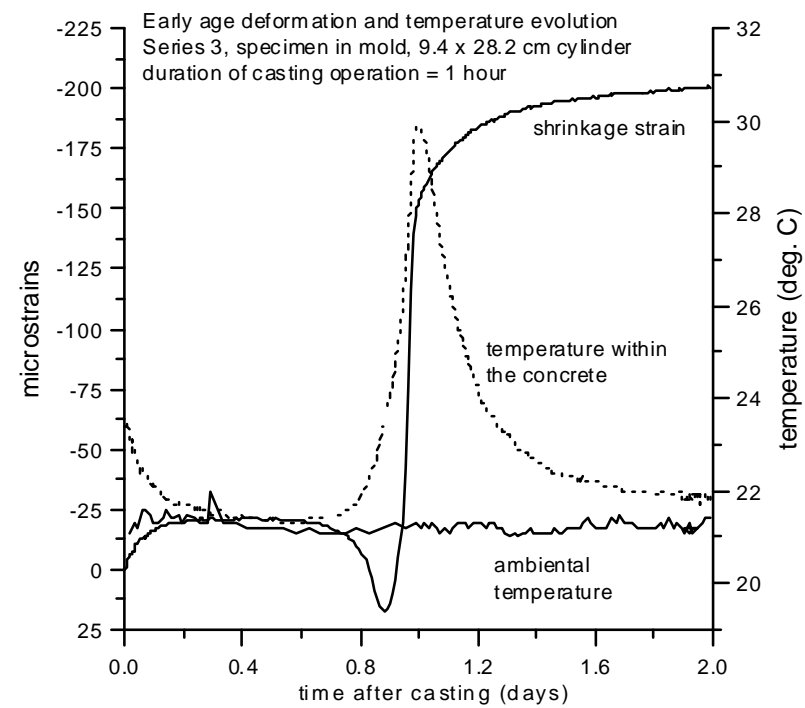

Figure 5. Short-term temperature and shrinkage evolution

\section{Basic shrinkage and drying shrinkage}

The basic shrinkage, also called endogenous shrinkage, is the deformation in a specimen that has been maintained at constant temperature and without humidity change with the environment. The quantification of this deformation has been made using the wet chamber ( $100 \%$ H.R.) during the period of cure, and using a sealed during the period of the test in the environment of the climatic chamber $(50 \pm 5 \%)$. Figure 6 presents the curves of the basic shrinkage of the concrete of the series 2 and 5, measured since the beginning of the period of cure in the wet chamber. Through this figure it is verified that the basic shrinkage of the high strength concrete is considerable and, therefore, it must be considered in the behavioral forecast models of the material. For a period of 3 months, that deformation reaches about $450 \mathrm{~mm} / \mathrm{m}$ (Series 2). This phenomenon is very different for normal concretes, which almost do not present basic shrinkage. On the other hand, it is observed in this figure that the concrete of the series 2 that carries a high quantity of paste presents greater basic deformation that the concrete of the series 5 (about 3,3 times), for the same water/cement ratio. Then, the effect of the volume of paste in the concrete must also be considered in the behaviour models of the material.

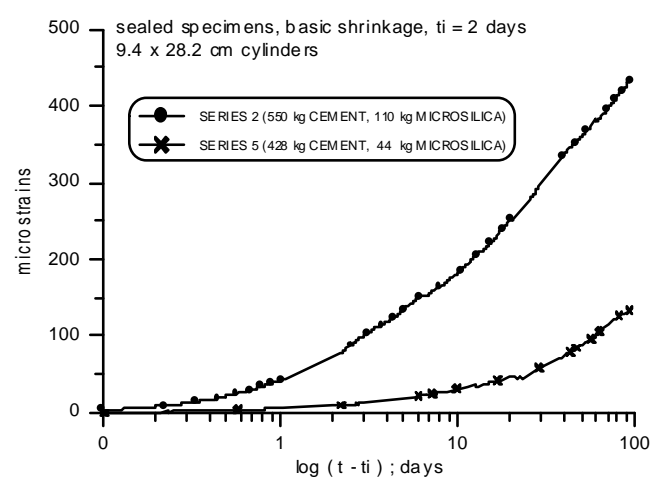

Figure 6. Deformations of basic shrinkage

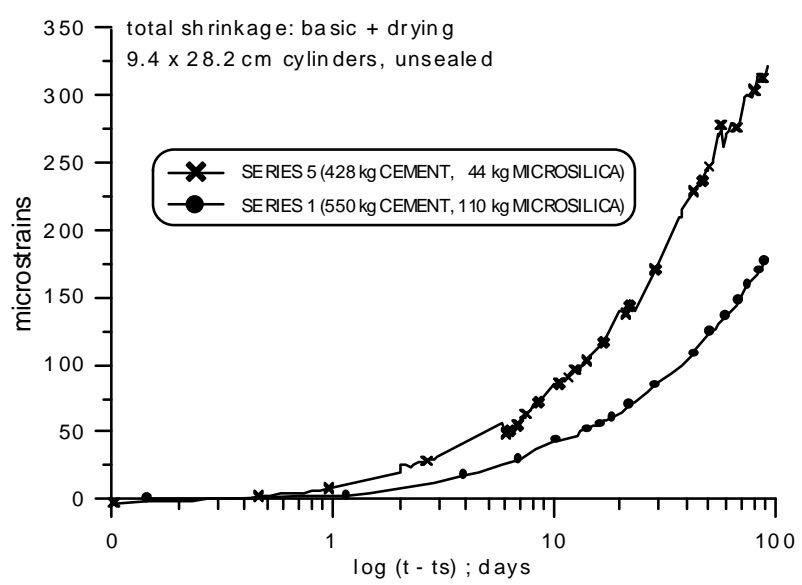

Figure 7. Deformation of total shrinkage : basic + drying

The total shrinkage is measured in a specimen exposed to the drying process, after the cure in the wet chamber by a period of 28 days (ts). Figure 7 presents the curves of the shrinkage measured in the specimens of the concrete of the series 1 and 5, during a period of 3 months. The total shrinkage (basic + drying) of the concrete of the series 5 is about 1,8 times greater than that of the series 1 , against the basic shrinkage deformations of the series 2 and 5 (Figure 6). This is due to the fact that the series 2 concrete has less free water due to the internal selfdessication suffered during the curing time, generated by the high paste content. During the 3 months period of testing in the climatic chamber, the concrete of the series 5 presented a proportion about $30 \%$ of basic shrinkage and $70 \%$ of drying shrinkage, and the concrete of the series 1 presented about $75 \%$ of basic shrinkage and $25 \%$ of drying shrinkage, related to 
the total shrinkage deformation measured for each one of the series. These results agree with the previous conclusions, where the concrete with greater paste content presented greater basic shrinkage proportion on the total deformation.

\section{Basic creep and drying creep}

Similarly to the shrinkage, the creep should also be differentiated in terms of: basic creep and drying creep. They are affected by the same variable that the shrinkage, but they are also influenced by the type of load, the magnitude and duration of this. The basic creep is obtained in the absence of humidity exchange with the environment (sealed specimens were used), and the drying creep is obtained from an unsealed specimen in a controlled environment (HR $=50 \pm 5 \%$ ) less the creep observed in the sealed specimen. To compare the results obtained in the tests accomplished in the present work, the results are presented in Table 2 in terms of the creep coefficient, that relates the creep deformations (they do not include the shrinkage) to the instant deformations. Such coefficients are given due to the type of concrete, size of the specimen, tension and condition level of exposition, with load for a period of 3 months. From these results the following considerations can be made:

- the basic creep coefficient represents about $85 \%$ of the total creep for the concrete of the series 1 and 2, and $70 \%$ for the concrete of the series 3, 4 and 5. This means that the basic creep is the most important part of the total creep of the high strength concrete, but the results show that the drying deformations can not be despised.
- the total creep coefficients (basic + drying) of the concrete of the series 3, 4 and 5 are slightly greater than that of the series 1 . These results indicate that the concrete of the series 2 is more compact, and, therefore, the creep coefficient of the concrete could be associated to compressive strength.

- the creep coefficient does not vary significantly with the tension level until $40 \% \mathrm{fc}_{\mathrm{c}}$. That means that, at least for this tension range, the analyzed concrete present a linear creep behaviour.

- It has been noted that the H.S.C. presents a reduction of the creep coefficient compared to the conventional concrete. If $70 \%$ of the last creep occurs in the first three months (SWAMY, 1986), then, the last creep coefficients expected from the sealed specimens, of Table 2 , would remain between 0,85 and 1,00 ; and the unsealed specimens, between 1,15 and 1,40 . On the other

Table 2. Creep coefficient to $\left(\mathrm{t}-\mathrm{t}_{\mathrm{o}}\right)=3$ months; Series of 1 to 5

\begin{tabular}{|c|c|c|c|c|c|c|}
\hline \multirow{3}{*}{ SERIES } & \multirow{3}{*}{$\begin{array}{c}\mathrm{f}_{\mathrm{C}}(\mathrm{MPa}) \\
\text { age at loading (days) }\end{array}$} & \multirow{3}{*}{$\begin{array}{c}\text { size of } \\
\text { cylinders }(\mathrm{cm})\end{array}$} & \multicolumn{4}{|c|}{ CREEP COEFFICIENT } \\
\hline & & & \multicolumn{2}{|c|}{$F=20 \% f_{c}$} & \multicolumn{2}{|c|}{$F=40 \% f_{c}$} \\
\hline & & & sealed & unsealed & sealed & unsealed \\
\hline \multirow{2}{*}{1} & \multirow{2}{*}{$87\left(t_{0}=35\right)$} & $9,4 \times 28,2$ & - & 0,80 & - & 0,85 \\
\hline & & $15 \times 45$ & - & 0,83 & - & - \\
\hline \multirow{4}{*}{2} & \multirow{4}{*}{$83\left(\mathrm{t}_{0}=23\right)$} & \multirow[t]{2}{*}{$9,4 \times 28,2$} & & - & 0,70 & - \\
\hline & & & 0,69 & - & 0,72 & - \\
\hline & & \multirow{2}{*}{$15 \times 45$} & 0,71 & - & - & - \\
\hline & & & 0,72 & - & - & - \\
\hline \multirow{2}{*}{3} & \multirow{2}{*}{$75\left(\mathrm{t}_{\mathrm{o}}=28\right)$} & \multirow{2}{*}{$9,4 \times 28,2$} & 0,60 & 0,87 & 0,65 & 0,98 \\
\hline & & & - & - & 0,63 & 0,94 \\
\hline \multirow{2}{*}{4} & \multirow{2}{*}{$64\left(t_{0}=28\right)$} & \multirow{2}{*}{$9,4 \times 28,2$} & 0,56 & 0,83 & 0,62 & 0,98 \\
\hline & & & 0,58 & 0,86 & 0,60 & 0,92 \\
\hline \multirow{2}{*}{5} & \multirow{2}{*}{$65\left(\mathrm{t}_{0}=28\right)$} & \multirow{2}{*}{$9,4 \times 28,2$} & - & - & 0,55 & 0,97 \\
\hline & & & - & - & 0,64 * & $0,95 *$ \\
\hline
\end{tabular}

* Laboratory ambient $\left(40 \%<\right.$ R.H. $\left.<80 \%, \mathrm{~T}=21 \pm 5^{\circ} \mathrm{C}\right)$ 
hand, considering that $50 \%$ of the last creep occurs in the first three months (NEVILLE AND BROOKS, 1987), the last creep coefficients expected from the sealed specimens would remain between 1,20 and 1,40; and of the unsealed specimens, between 1,60 and 1,95.

\section{Discussion}

The above results indicate that there are several aspects of the short- and long-term mechanical behaviour that are unique to some high performance concretes, and should be quantified properly. Besides, this quantification is affected by several experimental parameters, which have to be further studied and standardized. The creep coefficients that were obtained in this study are plotted along with other data from the literature in Figure 8. A general trend can be identified where the creep coefficient decreases with an increase in the compressive strength of concrete, which is useful from the practical engineering point of view. However, it should be noted that the strength is not the only parameter that governs the creep behaviour of such concretes.

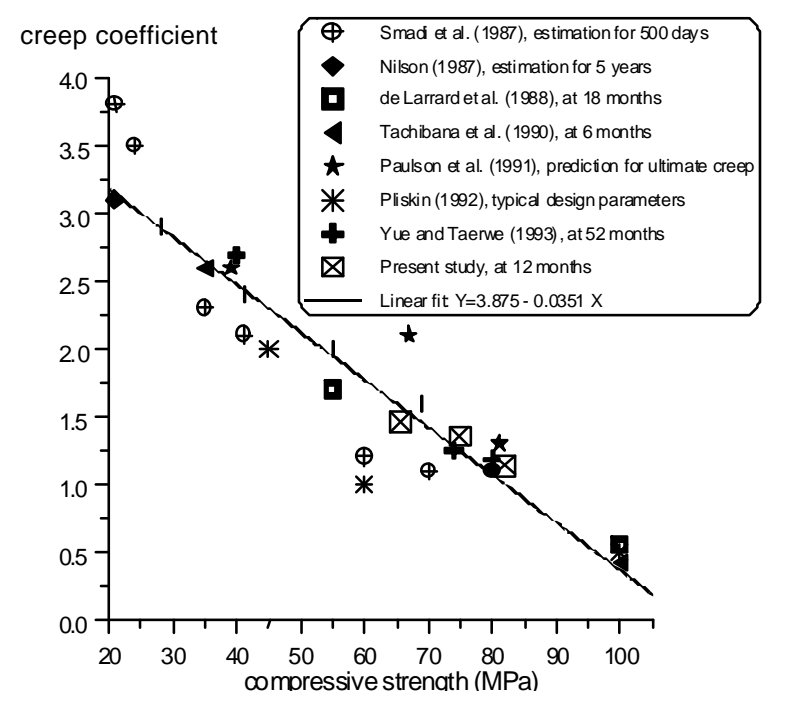

Figure 8. The creep coefficients this study are plotted along with other data from the literature

\section{Conclusions}

- A methodology for the study of creep and shrinkage in high strength silica fume concretes has been validated. The test setup includes a rigid oleopneumatic frame, a loading jack, a nitrogenoil accumulator, a load cell, an electronic data acquisition system controlled with a computer and a chamber with controlled environment. The use of embedded and/or bonded strain gages to the measurement of deformations is recommended.

- The simple method of sealing the specimen with paraffin and aluminum foil seems to be adequate for determining basic creep and endogenous shrinkage.

- The utilization of the mean deformation from at least three bonded strain gages is recommended when no embedded sensor is used.

- The endogenous shrinkage in the studied concretes is significant, even at $100 \%$ R.H. or in sealed conditions.

- The deformations due to basic creep are much larger than those due to drying creep in the studied concretes.

- The results show that drying creep is recoverable while the part not recoverable corresponds to the basic creep. Not all the changes of micro-structure are reversible.

- The effect of the volume of paste in the concrete must also be considered in the behaviour models of the material. The concrete with greater paste content presented greater basic shrinkage proportion on the total deformation.

- The use of cylinders with diameters of about 10 $\mathrm{cm}$ in creep tests is possible and should be studied further. 


\section{Acknowledgments}

The authors gratefully appreciate the financial support from CICYT grants (MAT93-0293 and MAT95-1906-CE) to the UPC. The stay of G.Carbonari at the UPC was funded through partnership between CAPES (Brazil) and the State University of Londrina (Brazil). The experimental study was conducted in the Structural Technology Laboratory of the UPC.

\section{References}

ASTM. Standard Test Method For Creep of Concrete in Compression, C 512-87. In: AMERICAN SOCIETY FOR TESTING AND STANDARDS. Annual Book of Standards. Philadelphia, 1987. v.04.02.

ACKER, P. Recommendation for Measurement of Time-Dependent Strains of Concrete Loaded in Compression. In: BAZANT, Z.P.; CAROL, I.; SPON, F.N. (Eds.). Creep and Shrinkage of Concrete. London: Chapman Hall, 1993. p.849-858.

CARBONARI, G. Comportamiento mecánico instantáneo y diferido del hormigón de alta resistencia. 1996. Tese (Doutorado) - Universitat Politècnica de Catalunya, Barcelona, 1996.

DE LARRARD, F.; MALIER, Y. Engineering Properties of Very High Performance Concretes. In: MALIER, Y.E.; SPON, F.N. (Eds.). High Performance Concrete: From Material to Structure. London, 1992. p.85-114.

FAVRE, R.; CHARIF, H.; JACCOUD, J. P. Large Reduction of Deflections Due to HPC. In: Malier, Y. (ed.) High Performance Concrete: From Material to Structure. London: E\&FN Spon, 1992. p.160-185.
LE ROY, R.; DE LARRARD, F. Creep and Shrinkage of High-Performance Concrete: The LCPC Experience Creep and Shrinkage of Concrete, editors: Z.P.Bazant and I.Carol, E\&FN Spon, London, pp. 499-504, 1993.

NEVILLE, A.; BROOKS, J.J. Creep and shrinkage of concrete as affected by admixtures and cement replacement materials. In: MALHOTRA, V.M. (Ed.). Fly ash, silica fume, slag, and natural pozzolans in concrete. Detroit: ACI SP-132, 1987. p.19-35.

SWAMY, R. N. Properties of high strength concrete. Cement, Concrete, and Aggregates, CCAGDP, v.8, n.1, p.33-41, 1986.

TAZAWA, E.; MIYAZAWA, S. Autogenous Shrinkage of Concrete and Its Importance in Concrete Technology. In: BAZANT, Z.P.; CAROL, I.; SPON, F.N. (Eds.). Creep and Shrinkage of Concrete. London: Chapman Hall, 1993. p.159-168.

TAZAWA, E.; MIYAZAWA, S.; KASAI, T. Chemical Shrinkage and Autogenous Shrinkage of Hydrating Cement Paste. Cem. Concr. Res., v.25, n.2, p.288-292, 1995.

VERNET, C.; CADORET, G. Monitoring of the Chemical and Mechanical Changes in High Performance Concretes During the First Days. In: MALIER, Y.E.; SPON, F.N. (Eds.). High Performance Concrete: From Material to Structure. London, 1992. p.145-159. 